\title{
HUMAN RIGHTS IN THE DIGITAL ERA: CHALLENGES AND OPPORTUNITIES FROM THE UNITED NATIONS HUMAN RIGHTS SYSTEM
}

\author{
DANIELA GONZÁLEZ IZA*
}

\begin{abstract}
One of the most important changes in our era is the ones promoted by the digital technology, which has meant a challenge in the promotion of human rights. Not only do we talk about the vulnerability to privacy, but also the possible biases of algorithms and other risks that represent potential violations to human rights. International organizations, such as the United Nations, have taken this issue in their hands, although the lack of development of norms regarding digital technology and human rights. The main objective of this paper is to analyze the way the non-conventional and conventional mechanisms of the United Nations Human Rights System have treated this issue. Through a document review, some actions and interpretations made by these will be analyzed, in order to determine some opportunities and challenges in the way the United Nations has approached to this issue.
\end{abstract}

Keywords: United Nations; Human rights; Digital technology

\section{INTRODUCTION}

One of the most important characteristics in modern society is the use of digital technology in our daily lives. The benefits of the so-called digital era have been evident: the acceleration in communication processes, the use of artificial intelligence and generation of data. However, some of the greatest challenges have to do with the respect of human rights.

"The same human rights exist inside and outside Internet" (Bachelet 2019). This phrase can tell us a lot about the relevance of human rights in the digital era; however, it is still general in providing evidence of how to face the challenges in the incorporation of this perspective, especially in the case of how international institutions, such as the ones of the United Nations Human Rights System. This essay explores the way the United Nations has addressed the challenges to respect to human rights posed by the digital technology.

To answer this question, it is necessary to understand what the main characteristics of the digital technology are, taking into account positive and negative aspects. From a general valuation of how the institutions of the United Nations Human Rights System address these challenges, it will be possible to identify some lessons that represent challenges and opportunities in the protection of human rights.

The first part of this article will focus on literature review about the main critics that new technologies have represented to the respect of human rights. After this review, a brief description of the function of the United Nations Human Rights System will be made, in order to identify the kind of institutions that have been involved in the adoption of official documents about new technologies and human rights. Some analyses to these documents will be made to understand some challenges that these institutions have had in addressing this issue.

One the most active institutions inside the United Nations in the issue of digital era and human rights is the Secretary General, which has adopted a new strategy concerning these new 
technologies (United Nations 2018). However, the topics and the ways other mechanisms of the United Nations Human Rights System have approached is totally different. This situation not only shows different concerns across the United Nations human rights institutions, but also some important challenges ahead.

\section{WHAT IS THE DIGITAL ERA?}

From tools to obtain, save and process data, artificial intelligence that analyzes data and predicts behavior, to the so called "Internet of things" and net infrastructure, a major flow of information and digitalization of our lives have been generated. These technological improvements have been part of something known as "disruptive technologies"; technologies that are capable of completely changing our environment. The use of these technologies has been accelerated in the last years, due to the direct and indirect effects of COVID-19 pandemics (Venkatasubramanian 2020).

Nowadays, the impact of digital technology is even greater. New applications related to data processing, such as artificial intelligence created for decision making, have been a positive change marker in some fields such as education, jobs and trade. Actually, digital technology has been recognized as a powerful tool to promote the Sustainable Development Goals (Guterres, The age of digital interdependence 2019). However, some relevant debates about the application of these technologies have been made, especially those concerning their development and the creation of new responsibilities to protect human rights by other international actors, such as multinational corporations.

One first critique about the challenges posed by the new digital technologies to the protection of human rights has to do with their design and the lack of transparency. Scholars such as Lorna McGregor, Daragh Murray and Vivan Ng (2019) refer to the need to warrant transparency in the development of digital technologies, as essential part of what is known as algorithmic responsibility: from the logics of the model of these technologies to its follow-up.

The development of digital technology has been, in a certain way, "a black box", because individuals do not know about the transparency in the decision-making processes in making these technologies. Furthermore, there are new agents (such as corporations) involved in the design, application and follow up of digital technologies that must be responsible of possible scenarios of vulnerability of human rights; however, they are incentivized by their own private interests.

The analysis about the diverse actors that participate in the development of these new technologies, as well as their responsibilities, are not only reduced to the private economic interests, but also to the way information is managed, taking into account that data is already an end itself. Management of information can affect integrity of individuals or social cohesion (Colmenarejo Fernández 2017). Digital technologies are also social constructs; thus, their development is not transparent or neutral (Gerards 2019), having consequences in human rights field.

Which risks does digital technology pose to human rights? In addition to the need of making a more inclusive world in the face of the Internet growth, discrimination and infringement to privacy are the most common scenarios. For example, algorithms can create generalized behaviors for a specific social group, not for individuals, creating certain kind of biases or inadequate real time responses that could discriminate in specific situations (McGregor, Murray \& Ng 2019). Also, lack of transparency in the design of these technologies, a non-contextual use of information or a generalized use of data in every situation can have as consequence the perpetuation of structural inequalities or vulnerability in the case of privacy 
protection of individuals (Pizzi, Romanoff \& Engelhardt 2020). Finally, democracies can be at risk with the strengthening of surveillance of citizens in this new era (Larson 2018).

While it is true that many states have adopted policies about certain issues related with digital technology (McGregor, Murray \& Ng 2019), this particular topic has become profoundly complex for international institutions, such as the United Nations. A general support to talk about this topic from the lens of International Human Rights Law is necessary, in particular, the role of United Nations Human Rights System. However, have the United Nations institutions been successful in incorporating this perspective? Which challenges do we have ahead in the respect of human rights in the digital era?

\section{A BRIEF INTRODUCTION TO THE UNITED NATIONS HUMAN RIGHTS SYSTEM}

The adoption of the Universal Declaration of Human Rights in 1948 meant a significant step in the creation of international norms of human rights, as well as international human rights regimes. Although there is a debate about the efficiency of these international mechanisms due to the fact that they are strong in the promotion of human rights norms, but weak in its implementation (Donnelly 2013), they provide a common language and spaces of participation for other international actors. That is the reason why the United Nations Human Rights System is perceived as one of the best for discussing topics such as respect of human rights in the digital era.

The United Nations Human Rights System is organized in a complex network of institutions that provide an enriched observance of international norms of human rights, even though it represents a challenge in promoting a major coordination among the institutions of this system. According to Carlos Villán Durán (2018), the United Nations Human Rights System is composed by more than 200 international treaties, among others, judicial instruments and bodies that look after the implementation of these norms.

The United Nations Human Rights System is divided into two types of institutions, based on their origin: non-conventional mechanisms and conventional mechanisms (also known as human rights committees or human rights treaty bodies). The first ones were created by one of the main bodies of the United Nations (for example, the Secretariat, the General Assembly, and Security Council). Some of the most important institutions of this type are the Human Rights Council (which depends on the General Assembly) and the Office of the High Commissioner for Human Rights (which depends on the Secretary General), because they promote a deeper cooperation with states through political means, such as the channels offered by the Human Rights Council.

The human rights treaty bodies have been created from a particular human right convention and are conformed by independent experts chosen individually and who are responsible of monitoring the commitment of the states to a particular human rights conventions. Although this institutional network tends be complex in the processes of monitoring (for example, the committees have different working methods in the consideration of states' reports, consideration of individual complaints, and in the conduct of country inquiries), it offers the opportunity to generate a constructive dialogue with states parties through specialized channels that enable a more precise evaluation of the application of international adopts ratified by states.

Valentina Carraro (2019) has identified the strength of each type of these institutions. In the case of non-conventional mechanisms, the most important one is the Human Rights Council, which, through its main monitoring process, (Universal Periodic Review) can publicly generate certain kind of pressure to the states. In the case of the human rights treaty bodies, the evaluation of certain situations of human rights is generated with a major level of expertise. 
The Office of the High Commissioner of Human Rights is the agency responsible of the coordination of all these institutions, and, therefore, is considered one of the main pillars in the international human rights system (Charlesworth 2017).

The United Nations Human Rights System has been the most important regime of international human rights law. However, all the most relevant human rights treaties were ratified during before the digital era and the challenges that the new digital technologies have posed on human rights are just being analyzed.

\section{THE UNITED NATIONS HUMAN SYSTEM IN THE FACE OF THE DIGITAL ERA}

The need to respect human rights has been called under new circumstances revealed by the incorporation of digital technologies in our daily lives. Many authors proclaim the urgency of having the United Nations as the official spokesperson in order to generate consensus about strategies of protecting human rights in this new era (McGregor, Murray \& Ng 2019; Pizzi, Romanoff \& Engelhardt 2020; Gottardo 2021). How have the diverse institutions inside the United Nations Human Rights System responded to the challenges posed by the digital era?

To begin with, human rights protection in the age of digital technologies has been a topic of concern to the Secretary General of the United Nations, as demonstrated in its Strategy of New Technologies. The most important commitments adopted by the Secretary General have to do with: (1) increasing UN's internal capacities and exposure to new technologies; (2) increasing understanding and dialogue with other international actors, (3) supporting cooperation networks, and (4) enhancing UN support to government capacity development. By doing this, the main objective is to ensure that new technologies accomplish the principles of international human rights law (United Nations 2018).

In 2018, the Secretary General's Digital Cooperation Panel was established. This panel consists of more than twenty political representatives, academics, entrepreneurs and civil society. The main objective of this panel was to discuss different ways in which digital technology has permeated in societies at a transnational level, identifying some fields of cooperation among different international actors.

The recommendations made by this panel were: Internet universal access, promotion of digital public goods, digital inclusion for everyone, international support for the development of artificial intelligence, and protection of human rights in the digital era (United Nations 2020). In this last point, it is important, according to the Panel, to review how the currents human rights standards function in the face of technological changes, especially in the face of the problems that have been identified as posing a risk in respect of human rights: (1) data protection and privacy; (2) digital identity; (3) monitoring technologies, such as facial recognition; and (4) online harassment and violence (Guterres 2020).

More recently, the Secretary General has focused on the fulfillment of the Sustainable Development Goals in the digital era through the analysis of the role of the new technologies in the realization of economic, social, and cultural rights. Although there are positive aspects about the use of digital technologies in a life with dignity (for example, in the sectors of education and health), some concerns identified have to do with the continuous pattern of discrimination in the digital era, the lack of accountability by the companies who develop these technologies, the vulnerability of privacy in defense of security issues, and the so called digital divide (United Nations 2020).

There has been an increasing interest by the current United Nation Secretary General, António Guterres to address the main challenges posed by the development of digital technologies. There is an increasing interest to work with different stakeholders, such as corporations, civil society organizations, and academy, as to identify the ways United Nations 
can respond efficiently to these challenges. Some of these challenges have been also analyzed by the diverse institutions of the United Nations Human Rights System.

In the case of non-conventional institutions of the United Nations Human Rights System, some pronouncements have been made. For example, the General Assembly has adopted several resolutions in which the discussion of the challenges of the new digital technologies to human rights is present. Since 1990, this topic has been discussed from the from the perspective of the article 12 of the Universal Declaration of Human Rights, which states that no one shall be subjected to arbitrary interference with his or her privacy (Téllez Carvajal 2020).

More recently, the General Assembly adopted some decisions concerning the consecution of the Sustainable Development Goals. For example, one topic that has been analyzed since 2014 by the General Assembly has to do with the digital divide. According to resolution $\mathrm{A} / 69 / 204$, it has been recognized a crescent divide among countries in terms of the availability and use of technologies, which are necessary tools to provide solutions to development challenges (United Nations 2021).

In the case of the Office of the United Nations High Commissioner of Human Rights, some reports can be highlighted, especially those connected with the protection of personal data and the responsibility of corporations (B-Tech Project) (United Nations Office of High Commissioner of Human Rights 2021). The most important decision of the Commissioner of Human Rights has been the exploitation of certain technologies for information processing in relation to human rights, such as the automation of the Human Rights Index (United Nations Office of High Commissioner of Human Rights 2021).

The Human Rights Council has dealt with these issues from a different perspective. For example, the Council has adopted different resolutions about the respect of human rights in the era of Internet since 2012 (A/HRC/RES/20/8; A/HRC/RES/26/13; A/HRC/RES/32/13, and $\mathrm{A} / \mathrm{HRC} / \mathrm{RES} / 41 / 11)$. These resolutions talk about the need of mapping efforts inside the United Nations to deal with the opportunities and challenges posed by these new technologies. In resolutions A/HRC/RES/12/16 (2009) and A/HRC/RES/23/2 (2013), the topic of the impact of new technologies in freedom of speech has been analyzed.

There has been an effort to include a broader perspective of how to address this topic from the work of the Human Rights Council. For example, in a resolution adopted in 2019 (A/HRC/RES/41/11), the Human Rights Council talked about the need to analyze the responsibility of other actors in the respect of human rights in the digital era. Furthermore, the Council asked its Advisory Committee to make a compilation of all the resources and initiatives adopted by the Human Rights Council and convened a Panel Discussion on the impacts of digital technologies in the protection of human rights (Human Rights Council 2019).

The Panel, which took place in July 2020, had the participation of diverse NGOs dedicated to the defense of digital rights, representatives of states and United Nations institutions. One additional challenge has been analyzed: COVID-19 pandemic has accelerated the dependence on new technologies, but also has increased the divide on the access to them (United Nations Office of High Commissioner for Human Rights 2020). These recent developments adopted by the Human Rights Council has represented an additional effort of the Human Rights Council to identify the most important issues related to the vulnerability of human rights by digital technologies and generate certain kind of consensus about these topics inside the United Nations.

Some Human Rights Council's special mechanisms have dealt with this topic. For example, in several sessions of the Universal Periodic Review, some recommendations related to respect of human rights and digital technologies have been made to some examined countries (Brown \& Kumar 2016). In addition, as seen in Table 1, numerous reports from special rapporteurs and working groups have been published. 
Table 1. Main reports from special procedures of the United Nations Human Rights Council about the challenges of human rights in the digital era (1998-2020).

\begin{tabular}{|c|c|c|}
\hline Year & Report & Relevant topics \\
\hline 1998 & $\begin{array}{l}\text { Report of the Special Rapporteur on the } \\
\text { promotion and protection of the right to } \\
\text { freedom of opinion and expression, Abid } \\
\text { Hussain }\end{array}$ & $\begin{array}{l}\text { The impact of new information technologies in the } \\
\text { right to freedom of opinion. }\end{array}$ \\
\hline 2005 & $\begin{array}{l}\text { Report of the Special Rapporteur on the sale of } \\
\text { children, child prostitution and child } \\
\text { pornography, Juan Miguel Petit }\end{array}$ & Impact of Internet in children's vulnerabilities. \\
\hline 2007 & $\begin{array}{l}\text { Report of the Special Rapporteur on the } \\
\text { promotion and protection of the right to } \\
\text { freedom of opinion and expression, Ambeyi } \\
\text { Ligabo }\end{array}$ & Internet governance. \\
\hline 2009 & $\begin{array}{l}\text { Report of the Special Rapporteur on the sale of } \\
\text { children, child prostitution and child } \\
\text { pornography, Najat M'jid Maalla }\end{array}$ & Impact of Internet in children's vulnerabilities. \\
\hline 2010 & $\begin{array}{l}\text { Report of the Special Rapporteur of the Human } \\
\text { Rights Council on extrajudicial, summary or } \\
\text { arbitrary executions, Philip Alston }\end{array}$ & $\begin{array}{l}\text { Relevance of new technologies in human rights fact } \\
\text { findings, targeted killings and accountabilities. }\end{array}$ \\
\hline 2011 & $\begin{array}{l}\text { Report of the Special Rapporteur on the } \\
\text { promotion and protection of the right to } \\
\text { freedom of opinion and expression, Frank La } \\
\text { Rue }\end{array}$ & Relevance of Internet in freedom of expression. \\
\hline 2013 & $\begin{array}{l}\text { Report of the Special Rapporteur on the rights } \\
\text { to freedom of peaceful assembly and of } \\
\text { association, Maina Kiai }\end{array}$ & $\begin{array}{l}\text { Relevance of new technologies in the facilitation of } \\
\text { the organization of peaceful assemblies. }\end{array}$ \\
\hline 2013 & $\begin{array}{l}\text { Report of the Special Rapporteur on the } \\
\text { promotion and protection of the right to } \\
\text { freedom of opinion and expression, Frank La } \\
\text { Rue }\end{array}$ & $\begin{array}{l}\text { Evolution of Surveillance Technology and its } \\
\text { impact on freedom of expression. }\end{array}$ \\
\hline 2015 & $\begin{array}{l}\text { Report of the Special Rapporteur on the } \\
\text { promotion and protection of the right to } \\
\text { freedom of opinion and expression, David } \\
\text { Kaye }\end{array}$ & $\begin{array}{l}\text { The impact of encryption and anonymity on } \\
\text { freedom of speech. }\end{array}$ \\
\hline 2016 & $\begin{array}{l}\text { Report of the Special Rapporteur on the } \\
\text { promotion and protection of the right to } \\
\text { freedom of opinion and expression, David } \\
\text { Kaye }\end{array}$ & $\begin{array}{l}\text { Review of applicable legal framework to companies } \\
\text { in the digital age. }\end{array}$ \\
\hline 2017 & $\begin{array}{l}\text { Report of the Special Rapporteur on the } \\
\text { promotion and protection of the right to } \\
\text { freedom of opinion and expression, David } \\
\text { Kaye }\end{array}$ & Right to the access of information \\
\hline 2018 & $\begin{array}{l}\text { Report of the Special Rapporteur on the } \\
\text { promotion and protection of the right to } \\
\text { freedom of opinion and expression, David } \\
\text { Kaye }\end{array}$ & $\begin{array}{l}\text { Impact of artificial intelligence on freedom of } \\
\text { expression, privacy and non - discrimination. }\end{array}$ \\
\hline
\end{tabular}




\begin{tabular}{|c|c|c|}
\hline 2018 & $\begin{array}{l}\text { Report of the Special Rapporteur on the } \\
\text { promotion and protection of the right to } \\
\text { freedom of opinion and expression, David } \\
\text { Kaye }\end{array}$ & Regulation of online content. \\
\hline 2018 & $\begin{array}{l}\text { Report of the Special Rapporteur on violence } \\
\text { against women, its causes and consequences on } \\
\text { online violence against women and girls from } \\
\text { a human rights perspective, Dubravka } \\
\text { Šimonović }\end{array}$ & Online violence against girls and women. \\
\hline 2019 & $\begin{array}{l}\text { Report of the Special Rapporteur on the } \\
\text { promotion and protection of the right to } \\
\text { freedom of opinion and expression, David } \\
\text { Kaye }\end{array}$ & $\begin{array}{l}\text { Surveillance technologies and their impact on } \\
\text { freedom of expression. }\end{array}$ \\
\hline 2019 & $\begin{array}{l}\text { Report of the Working Group of Experts on } \\
\text { People of African Descent }\end{array}$ & Relationship between big data and racial justice. \\
\hline 2019 & $\begin{array}{l}\text { Report of the Special Rapporteur on extreme } \\
\text { poverty and human rights, Phillip Alston }\end{array}$ & $\begin{array}{l}\text { Concern about the emergence of the "Digital Social } \\
\text { State" and the interests of the companies behind } \\
\text { these programs. }\end{array}$ \\
\hline 2019 & $\begin{array}{l}\text { Report of the Independent Expert on the } \\
\text { enjoyment of all human rights by older } \\
\text { persons, Rosa Kornfeld-Matt }\end{array}$ & Impact of digital technology on older people. \\
\hline 2020 & $\begin{array}{l}\text { he Special Rapporteur on torture and other } \\
\text { cruel, inhuman or degrading treatment or } \\
\text { punishment, Nils Melzer }\end{array}$ & Cybertorture. \\
\hline 2020 & $\begin{array}{l}\text { Report of the Special Rapporteur on the right } \\
\text { to education, Koumbou Boly Barry }\end{array}$ & $\begin{array}{l}\text { Effects of digital learning during COVID-19 } \\
\text { pandemic. }\end{array}$ \\
\hline 2020 & $\begin{array}{l}\text { Report of the Special rapporteur on the } \\
\text { promotion and protection of the right to } \\
\text { freedom of opinion and expression, David } \\
\text { Kaye }\end{array}$ & $\begin{array}{l}\text { Relevance of digital connectivity and digital access } \\
\text { to health-care information. }\end{array}$ \\
\hline 2020 & $\begin{array}{l}\text { Report of the Special Rapporteur on the right } \\
\text { of physical and mental health, Tlaleng } \\
\text { Mofokeng }\end{array}$ & Impact on digital surveillance on mental health. \\
\hline 2020 & $\begin{array}{l}\text { Report of the Special } \\
\begin{array}{l}\text { Rapporteur on } \\
\text { extrajudicial, summary, } \\
\text { executions, Agnes Callamard. }\end{array}\end{array}$ & Impact of the proliferation of use of drones. \\
\hline 2020 & $\begin{array}{l}\text { Report of the Special Rapporteur on the rights } \\
\text { to freedom of peaceful assembly and of } \\
\text { association, Clément Nyaletsossi Voule }\end{array}$ & $\begin{array}{l}\text { Effects of new technologies in the right of peaceful } \\
\text { assembly and association. }\end{array}$ \\
\hline
\end{tabular}

Source: United Nations (2021)

One of most involved rapporteurs in addressing the challenges posed by new digital technologies has been the Special Rapporteur on the rights to freedom of opinion and expression. Since 1998, these rapporteurs have analyzed diverse problems related with new technologies and freedom of expression, such as the contemporary restrictions to this rights: 
surveillance mechanisms, Internet shutdowns, limited access to online information, and limitations based on the discourse of national security rationale. It has to been noted that one of the topics that has been recently analyzed with more attention is the responsibility of corporations in the development of surveillance (Kaye 2019).

Although the main issues have to do with challenges that digital technologies have on freedom of expression and the right to privacy, there have been other topics that have addressed by rapporteurs, such as Philip Alston, Special Rapporteur on extreme poverty and human rights. During his visit to United Kingdom in 2018, in reference to evolution to digital welfare state, Alston concluded that "the British welfare state is gradually disappearing behind a webpage and an algorithm, with significant implications for those living in poverty" (Alston 2019).

Recently, other rapporteurs and working groups have analyzed some challenges related to the perpetuation of discrimination among vulnerable groups. Some of the topics that have been discussed is the effect of hate speech or online harassment, such as cyberbullying. Also, the respect of the rights of other groups have been analyzed, such as the right of older people to enjoy digital technologies. Finally, some rapporteurs have talked about the digital divide in COVID-19 pandemic (for example, in terms of education).

Even, some mechanisms have pointed out the risks of Internet as a space of conducting crimes, torture or arbitrary detentions. For example, the Special Rapporteur on the sale of children, child prostitution and child pornography has discussed the risks related to the use of new technologies in the case of child pornography and the way the corporations can be useful in the prevention of this crime. Another interesting case is the definition of cyber torture by the Special Rapporteur on torture and other cruel, inhuman or degrading treatment or punishment.

The most active non-conventional mechanisms of the United Nations Human Rights System in analyzing diverse challenges of new digital technologies in human rights have been the special procedures of the Human Rights Council. It is important to distinguish the character of the special rapporteurs, independent experts or working groups: their mandate is based on their expertise. The information they gather comes from country visits, communications and interaction with NGOs. However, some rapporteurs have been involved more deeply in these challenges, for example Philip Alston or David Kaye.

Finally, in the case of the United Nations treaty bodies, the challenges posed by digital technologies on the respect on human rights has been explored with less intensity, even though certain digital technologies have been included in the sessions of this mechanisms and their working methods (De Frouville 2021). The human rights committees that have been more proactive in talking about the protection of human rights in the face of digital era are: the Committee of Human Rights, the Committee on the Rights of Persons with Disabilities, and the Committee on the Rights of the Child. All of them have made general recommendations about diverse issues related to human rights and the digital era (Table 2).

Table 2. General Observations of the human rights treaty bodies related to the warranty of human rights in the digital era.

\begin{tabular}{ll}
\hline \multicolumn{1}{c}{ Committee } & \multicolumn{1}{c}{ Actions } \\
\hline $\begin{array}{l}\text { Committee on the Elimination } \\
\text { of Racial Discrimination }\end{array}$ & $\begin{array}{l}\text { General Observation no. } 34 \text { (2011) - Racial discrimination against people } \\
\text { of African descent. } \\
\text { General Observation no. } 35 \text { (2020) - Combating racist hate speech. }\end{array}$ \\
\hline Human Rights Committee & $\begin{array}{l}\text { General Observation no. 16 (1998) - Right to privacy. } \\
\text { General Observation no. 37 (2020) - Right of peaceful assembly. }\end{array}$ \\
\hline $\begin{array}{l}\text { Committee on the Rights of } \\
\text { Persons with Disabilities }\end{array}$ & $\begin{array}{l}\text { General Observation no. 4 (2016) - Right to inclusive education. } \\
\text { General Observation no. 5 (2017) - Right to independent living. }\end{array}$ \\
\hline
\end{tabular}


General Observation no. 6 (2018) - Equality and non-discrimination.

General Observation no. 7 (2018) - Participation with persons with

disabilities in the implementation and monitoring the Convention.

$\begin{aligned} & \text { Committee on the Rights of } \\ & \text { the Child }\end{aligned}$
of the business sector on children's rights

Source: United Nations (2021); United Nations Office of High Commissioner for Human Rights (2021)

The most common topics have to do with discrimination and the right to peaceful assembly. In the first case, the Committee on the Elimination of Racial Discrimination has talked about the racist hate speech and the effect of Internet and social networking sites. Also, the Committee on the Rights of Persons with Disabilities has talked about the need to develop assistive technologies and promote more inclusion in education, health and political participation. In the second case, it is the Committee of Human Rights who has talked about the relevance of the protection of privacy and the importance of connectivity access to promote online peaceful assemblies.

Some observations promote the involvement of other international actors, such as corporations or civil society. For example, the Committee on the Rights of the Child talks about the responsibility of social media to avoid cyberbullying, cyber grooming, or human trafficking. The Committee on the Rights of Persons with Disabilities mentions the value of the incorporation of these technologies in the working methods of the Committee with other international actors, such as Non-Governmental Organizations.

The treaty bodies have been less involved in the new challenges posed by the digital era on human rights, although other mechanisms inside the United Nations have used the conventions as legal framework for interpretation. However, it is important to note that this conclusion is based on the general comments and not of considerations of states' reports, which can include certain interpretation. The general comments are the best opportunity, not only to prove an interpretation of the human rights conventions, but also to organize thematic discussions, which can allow participation of representatives of civil society, for example.

The involvement of the different mechanisms that conform to the United Nations Human Rights System in the topic of human rights and digital technologies is increasing. However, there are some considerable differences. The institution that has had a major activism in this topic, either through its processes (such as the Universal Periodic Review) or special procedures, is the Human Rights Council. In the case of the human rights treaty bodies, there are limited mentions to the topic, although there is a concern about the incorporation of these new technologies in the working methods of the committees, especially in the face of a future evaluation of the functioning of these committees.

\section{DISCUSSION}

This documentary review about the actions that the institutions of the United Nations Human Rights System have taken to handle the protection of human rights in the face of the digital era open a new perspective about the opportunities and challenges in this area. Some lessons are related to the necessary perspective of human rights in the debate about the digital era, the involvement of international organizations, such as the United Nations, and the diluted responsibilities of other international actors, such as multinational corporations.

The first main challenge in the inclusion of human rights perspective in the digital era has to do with the way existing international human rights norms can be used. Are human rights 
treaties sufficient or is it necessary to negotiate new norms? The United Nations Human Rights System has more than 200 international treaties (Villán Durán 2018), all of them ratified in a pre-digital era. Many authors talk about the positive aspects of incorporating existing international human rights norms (McGregor, Murray \& Ng 2019; Woods 2019; Gottardo 2021). However, some deficiencies of this regime must be acknowledged, according to Mutua (2016) and Pizzi, Romanoff and Engelhardt (2020). We can consider the relevance of International Human Rights Law in the process of socialization of norms.

Human rights norms are product of claims and social struggles. We must consider that there are different pillars in the generation of commitments in International Human Rights Law that go beyond norms, there is a value system in this international regime (Cole 2012). This situation can make general principles of human rights adapt to the urgent approaches about the challenges of the technological advances.

Another interesting debate has to do with the viability of the United Nations, as the most important forum for the promotion of the respect of human rights in the digital era. According to António Guterres (2019), United Nations Secretary General, this organization provide an excellent space of negotiation of new norms, ratification of new standards and technical cooperation. However, there is no coordination between the different mechanisms of the United Nations Human Rights System.

There are some wrong perceptions about which institutions in the United Nations have been more active in this issue. There is a perception that the human rights treaty bodies have been extremely active; however, that is not the case. The good news is that other mechanisms, such as the special rapporteurs of the Human Rights Council, have been extremely purposeful. It is necessary to promote more institutional coordination among conventional and nonconventional mechanisms of human rights in the United Nations system, especially because this issue is new (Gottardo 2021). United Nations have some challenges ahead in the identification of scenarios of vulnerabilities of human rights in the face of digital technologies and some institutions inside the United Nations Human Rights System can prove to be more efficient.

Finally, there are concerns about the horizontal responsibility among different international actors. The inclusion of human rights perspective in the digital era provides not only a deeper commitment from states, but also the creation of responsibilities to private actors. How can we promote human rights in a sphere in which private interests do not match to these responsibilities? Which instruments can be effective in generating pressure to these actors (Pizzi, Romanoff \& Engelhardt 2020)? At the end, "technology only complements human experience, but it does not replace it" (Venkatasubramanian 2020)

Some opportunities of this analysis must be taken into account. This analysis only took general documents, and not states' reports, as in the case of treaty bodies. One further consideration can be a deeper analysis of the national reports to determine if this topic is present in treaty bodies. Also, it is important to note, in the case of the special procedures, the activism of some representatives and the way they try to make this issue visible to all the system. This can represent an opportunity area to see how these experts relate to diverse stakeholders; at the end, some NGOs can be detected or to analyze the factors behind their activism.

Finally, an opportunity for all the system has to do with the way coherence can be promoted. Although there have been some important efforts from the Secretary General, the Office of High Commissioner for Human Rights or the Human Rights Council to have certain coherence, it must be remembered that the impact of the digital era in human rights is a new topic which has been interpreted by former legal instruments. Definitely, this is the most important opportunity in the study of how the United Nations have addressed this topic. 


\section{CONCLUSION}

The protection of human rights in the face of the digital era has shown us, not only the problems (some new and some perpetuated as technologies are social constructs) in human rights realm, but also the instruments and necessary perspectives that must be adopted to face to these new challenges. Participation of all international actors is necessary. We no longer just talk about states: action from international organizations, such as the United Nations, is a priority.

The main objective of this essay was to explore the way in which United Nations has approached this subject. From a human rights perspective, a documentary review of different institutions of the United Nations Human Rights system has been made, in such a way that some vulnerabilities have been identified, from the treatment and processing of personal information to potentially discriminatory processes that can continue with these new technologies. Some lessons about the approach of United Nations institutions have been identified.

This study concluded that there are some lessons on the lack of consideration in the relationship between human rights and digital technologies. This issue forces us to question if existing international norms of human rights can respond to new realities posed by the digital era. On the other hand, it forces us to analyze to what extend institutions inside the United Nations can be efficient dealing with the debates from a human rights perspective.

The most important lesson is the questioning about what new realities in realm of human rights can represent. We are used to relate the respect of human rights as an exclusive responsibility of the states, as the main guarantors of these norms. To what extend are these principles also responsibility of other actors, such as corporations, for example? To what extend are we also responsible of the use of these new technologies?

Accelerated changes of our era have left us with more questions than answers, especially because of the paradigms changes we are living: information is power, and, in the face of these new realities of the digital era, power is totally diluted. United Nations must the forum to discuss the challenges that the digital era has posed on human rights. A promotion of deeper coherence among the institutions of the United Nations Human Rights System and identification of other international actors in this issue is the most important task to accomplish. It is more important than ever to talk about human rights as instruments of social claims in the face of diluted responsibilities.

\section{REFERENCES}

Alston, Phillip. 2019. Report of the Special Rapporteur on extreme poverty and human rights. A/HRC/41/39/Add.1. Geneve: United Nations.

Bachelet, M. 2019. Derechos humanos en la era digital. ¿Pueden marcar la diferencia? https://www.ohchr.org/SP/NewsEvents/Pages/DisplayNews.aspx?NewsID=25158\&L angID $=\mathrm{S}$ (Accesed 13 August 2021)

Brown, D., \& Kumar, S. 2016. Using the Universal Periodic Review for Human Rights online. London: Global Partners Digital.

Carraro, V. 2019. Promoting compliance with human rights: the performance fo the United Nations' Universal Periodic Review and Treaty Bodies. International Studies Quarterly 63 (4): 1079-1093.

Charlesworth, H. 2017. A regulatory perspective on the international human rights system. Regulatory theory: foundations and applications, Peter Drahos, Sidney: ANU Press: 357-373. 
Cole, W. 2012. Human rights as Myth and ceremony? reevaluating the effectiveness of human rights treaties, 1981-2007. American Journal of Sociology 117 (4): 1131-1171.

Colmenarejo R. 2017. Una ética para Big Data: introducción a la gestión ética de datos masivos. Barcelona: Editorial UOC.

De Frouville, O. 2021. The United Nations Treaty Bodies in a transition period - progress review March - December 2020 chronicle. Geneva: The Geneva Academy of International Humanitarian Law and Human Rights, Geneva University.

Donnelly, J. 2013. Universal human rights in theory and practice. Ithaca: Cornell University Press.

Gerards, J. 2019. The fundamental rights challenge of algorithms. Netherlands Quarterly of Human Rights 37 (3): 205-209.

Gottardo, R. 2021. Building global algorithmic accountability regimes: a future focused human rights agenda beyond measurement. Peace Human Rights Governance 5 (1): 65-96.

Guterres, A. 2019. The age of digital interdependence. New York: United Nations. https://www.un.org/en/pdfs/DigitalCooperation-report-for\%20web.pdf (Accesed 13 August 2021)

Guterres, A. 2020. Roadmap for Digital Cooperation. New York: United Nations.

Human Rights Council. 2019. New and emerging digital technologies and human rights. Resolution of the Human Rights Council of the United Nations. Geneve.

Kaye, David. 2019. Report of the Special Rapporteur on the promotion and protection of the right to freedom of opinion and expression. A/HRC/41/35. Geneve: United Nations.

Larson, C. 2018. Who needs democracy when you have data? MIT Technology Review. https://www.technologyreview.com/2018/08/20/240293/who-needs-democracy-whenyou-have-data/ (Accesed 13 August 2021)

McGregor, L., Murray, D., \& Ng, V. 2019. International Human Rights Law as a framework for algorithmic accountability. International and Comparative Law Quarterly 68 (2): 309-343.

Mutua, M. 2016. Human rights standards: hegemony, law and politics. New York: State Univeristy of New York Press.

Pizzi, M., Romanoff, M., \& Engelhardt, T. 2020. AI for humanitarian action: human rights and ethics. International Review of the Red Cross 913: 145-180.

Téllez, E. 2020. Análisis documental sobre el tema del big data y su impacto en los derechos humanos. Revista de la Facultad de Derecho 84: 155-206.

United Nations Office of High Commissioner for Human Rights. 2020. Human Rights Council holds panel discussion on emerging digital technologies; begins interactive dialogue with special rapporteur on internally displaced persons. https://www.ohchr.org/EN/NewsEvents/Pages/ (Accesed: 5 November 2021).

United Nations Office of High Commissioner of Human Rights. 2021. United Nations Human Rights Report 2020.

United Nations Office of High Commissioner of Human Rights. 2021. B-Tech Project. https://www.ohchr.org/EN/Issues/Business/Pages/B-TechProject.aspx （Accesed 13 August 2021).

United Nations Office of the High Comissioner for Human Rights. 2021. UN Treaty Body Database. https://tbinternet.ohchr.org/SitePages/Home.aspx (Accesed 13 August 2021).

United Nations. 2018. UN Secretary-General's Strategy On New Technologies. https://www.un.org/en/newtechnologies/ (Accesed 13 August 2021)

United Nations. 2020. Question of the realization of economic, social and cultural rights in all countries: the role of new technologies for the realization of economic, social and cultural rights. A/HRC/43/29, New York: United Nations. 
United Nations. 2021. Hub for Human Rights and Digital Technology. https://www.digitalhub.ohchr.org/ (Accesed 13 August 2021)

United Nations. 2021. Secretary-General's High-level Panel on Digital Cooperation. https://www.un.org/en/sg-digital-cooperation-panel (Accesed 13 August 2021)

Venkatasubramanian, A. 2020. The Human Rights Challenges of Digital COVID-19. Health and Human Rights Journal 22 (2): 79-80.

Villán Durán, C. 2018. La obligatoriedad jurídica de la Declaración Universal. In C. Proner, H. Olasolo, C. Villán Durán, \& G. Ricobom, $70^{\circ}$ aniversario de la Declaración Universal de Derechos Humanos. La protección Internacional de los Derechos Humanos en cuestión (págs. 113-122). Valencia: Tirant lo Blanch.

Woods, L. 2019. Digital privacy and Article 12 of the Universal Declaration of Human Rights. The Political Quarterly 90 (3): 422-429.

DANIELA GONZÁLEZ IZA

Instituto Tecnológico y de Estudios Superiores de Monterrey,

Campus Santa Fe, Universidad Loyola de Andalucía

Corresponding author: Daniela.iza@gmail.com

Received: 31 August 2021 / Accepted: 8 November 2021 / Published: 20 November 2021 